\title{
Antimicrobial property and phytochemical study of ginger found in local area of Punjab, Pakistan
}

\author{
Humayun Riaz ${ }^{1}$, Almas Begum², Syed Atif Raza ${ }^{3}$, Zia Mohy-Ud-Din Khan ${ }^{1}{ }^{*}$ Hamad Yousaf $^{1}$ and Ayesha Tariq ${ }^{4}$ \\ ${ }^{1}$ Rashid Latif College of Pharmacy Lahore, Pakistan \\ ${ }^{2}$ Rashid Latif Medical College Lahore, Pakistan \\ ${ }^{3}$ University College of Pharmacy, Punjab University, Lahore, Pakistan \\ ${ }^{4}$ Faculity of Pharmacy, University of Central Punjab, Lahore Pakistan
}

\begin{abstract}
The aim of study is to identify the antimicrobial property of ginger. Phytochemical screening of chloroform plant extract showed presence of different chemicals. In this study we used Cultures of E. Coli, Bacillus subtilis, Staphylococcus aureus and Streptococcus faecalis to identify the antimicrobial strength. Effectiveness of ginger against different conditions attributed to its different constituents (volatile oils, shogaols, Gingerols and diarylheptanoids) that show their therapeutic efficacy by modulating the genetic or metabolic activities of our body. In this study, we performed phytochemical evaluation and antimicrobial assay of ginger root extract which were available in our local farms of Lahore. Ginger possesses a noticeable antimicrobial activity which was confirmed by checking the susceptibility of different strains of bacteria and fungus by measuring the zone of inhibition. In the light of several socioeconomic factors of Pakistan mainly poverty and poor hygienic condition, present study encourages the use of spices as alternative or supplementary medicine to reduce the burden of high cost, side effects and progressively increasing drug resistance of pathogens.
\end{abstract}

Key Words: genus Zingiber, antimicrobial, phytochemical, rhizome.

\section{INTRODUCTION}

Rhizome or root part of ginger (genus Zingiber) (figure 1) is extensively employed in medicine for the management of different diseased conditions like nausea, vomiting, motion sickness, gastrointestinal ulcers, diabetes, fever, arterial tension, rheumatoid arthritis, dry mouth/ xerostomia, cancer, migraine headache, sore throat, minor respiratory ailments. Zingiber offcinale Roscoe, commonly known as Ginger, belongs to Zingiberaceae family (Kadnur and Goyal, 2005). Gengibre, Ancoas are the most frequently used Spanish names of Ginger (Ravindran and Babu, 2004; Maldonado, 2014) but in Pakistan, it is known as "Adrac" (Boyd, 1999).

Microbial pathogenecity and other infectious diseases have been controlled by use of commercially available antimicrobial drugs since last many years. Tremendous use of antibiotics has developed multiple drug resistance (MDR) in many bacterial pathogens. In the present study, in vitro antimicrobial activity of some local spices of Pakistan, that are routinely used in food, has been investigated against clinically important bacterial pathogens. South East Asia is considered as home grown land for Ginger production (Ravindran and Babu, 2004). By tradition, ginger farming is common in number of countries like Japan (Ravindran and Babu, 2004), China (Ravindran and Babu, 2004), Indonesia (Ravindran and Babu, 2004), Nigeria (Powell, 1986), India (Rahman et al., 2009), Brazil (Govindarajan and Connell, 1983), Sri Lanka (MacLeod and Pieris, 1984), the Philippines (Cramb et al., 2000) and Jamaica Islands (Ravindran and Babu, 2004). In Pakistan, commercial production of Ginger is not sufficient to converge its indigenous provisions (Iqbal et al., 2006) because its marketable cultivation is restricted to merely ten districts of Sindh (Panhwar, 2005). The best climate requirements for its cultivation are sandy clay (Bhosale and Shinde, 2011), semi-tropical (Chang et al., 2011) and temperate zone (Newman et al., 1997) with sufficient organic matter and $\mathrm{pH}$ of about 5.5-6.6 (Williams et al., 2003).

The horizontally solid underground stem / rhizome (with elegantly covered skin) of this plant has proved to be one of the most extensively used culinary agent and spice in daily home cooking practice (Naveena et al., 2004; Lantz et al., 2007). Despite of its use as flavoring agent, ginger is also appreciated in ayurvedic, tibbe-e-unani (Srivastava and Mustafa, 1989), allopathic (Fessenden et al., 2001), aromapethy (Shelly et al., 2004) and household medicines (Sloand and Vessey, 2001). Ginger rhizome can be employed in the form of fresh paste, ginger tea (flavoring), dried powder and preserved slices (El-Ghorab et al., 2010).

Ginger can be available in different commercial products like cookies, candy, teas, tinctures, sodas, jam, beer, capsule and syrup (Maxwell, 2008). The chief active constituents of ginger are Volatile oil (zingiberene, zingiberol, D-camphor), Shogaols, Diarylheptanoids, Gingerols, Paradol, Zerumbone, 1-Dehydro-(10) gingerdione, Terpenoids and Ginger flavonoids (Baliga et al., 2012). Shogaols and Gingerols are responsible for ginger's pungency (Suekawa et al., 1984). Ginger has wide range of biological activities that are attributed to its active constituents (Shukla and Singh, 2007); some of these are listed in table 1.
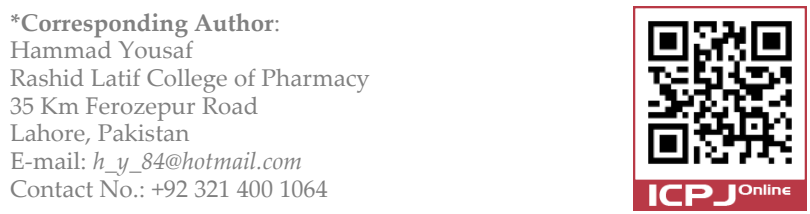


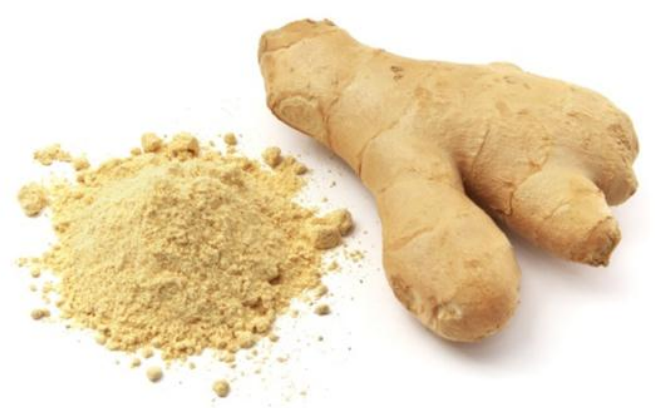

Figure 1: Ginger.

\section{MATERIALS AND METHODS}

\section{Plant material}

Ginger rhizomes were collected from a farm near Lahore, Pakistan in March 2014. Collection was performed by pulling plants out of the soil and transferring them into sealable plastic bags.

\section{Sample preparation}

The rhizomes were washed to remove soil, peeled and washed again in clean water. After washing, the rhizomes were dried, powdered and submitted to successive extraction by chloroform in separating funnel at room temperature. Collect the lower layer of chloroform in conical flask and heat the solution for a while. Chloroform will evaporate form flask and add water in this and mix. The extracts further sterilized by filtration $(0.22 \mu \mathrm{m})$.

Phytochemical screening of extract

In order to perform the phytochemical evaluation of ginger extract, methods already described in literature

Table 1: Biological activities of ginger reported in literatures.

\begin{tabular}{|c|c|c|c|}
\hline Active principles & Biological action & MOA & References \\
\hline $\begin{array}{l}\text { Gingerols, shogaols, Sesquit- } \\
\text { erpenes and monoterpenes) }\end{array}$ & $\begin{array}{l}\text { For the treatment of nausea } \\
\text { and vomiting }\end{array}$ & $\begin{array}{l}\text { By anticholinergic and antiserotonin } \\
\text { action }\end{array}$ & (Bryer, 2005) \\
\hline Ethanolic extract of ginger & Hypolipidimic agent & $\begin{array}{l}\text { By reducing triglycerides and LDL } \\
\text { cholesterol and to increase HDL }\end{array}$ & (Bolanle, 2011) \\
\hline [6]-gingerol & Anti-tumor property & $\begin{array}{l}\text { inhibition of NF- } \kappa \mathrm{B} \text {, stimulation of } \\
\text { apoptosis and inactivation of VEGF } \\
\text { pathways lead to antineoplastic } \\
\text { effects }\end{array}$ & (Surh et al., 1998) \\
\hline \multirow[t]{2}{*}{ 6-Shogaol } & Anti-inflammatory effect & $\begin{array}{l}\text { Inhibition of pro-inflammatory } \\
\text { cytokines (IL-12, TNF- } \alpha \text {, IL-1 } \beta, \text { IL-8) } \\
\text { and chemokines (RANTES, MCP-1). }\end{array}$ & (Penna et al., 2003) \\
\hline & $\begin{array}{l}\text { Anticancer activities (e.g. breast } \\
\text { cancer) }\end{array}$ & $\begin{array}{l}\text { inhibition of cell invasion reduction of } \\
\text { matrix metalloproteinase- } 9 \\
\text { expression }\end{array}$ & (Ling et al., 2010) \\
\hline $\begin{array}{l}\text { Zingiberone and ethanolic } \\
\text { extract of ginger }\end{array}$ & Anti-hyperglycemic effect & $\begin{array}{l}\text { Lowering of blood glucose level by } \\
\text { inhibition of oxidative stress and anti- } \\
\text { inflammatory process, increase } \\
\text { insulin sensitivity. }\end{array}$ & $\begin{array}{l}\text { (Vats et al., 2002; } \\
\text { Shanmugam et al., 2011) }\end{array}$ \\
\hline $\begin{array}{l}\text { 6-shogaol, phenolic and } \\
\text { favonoids compounds }\end{array}$ & Neuroprotector effect & $\begin{array}{l}\text { by accelerating brain anti-oxidant } \\
\text { defense mechanisms }\end{array}$ & (Shanmugam et al., 2011) \\
\hline $\begin{array}{l}\text { Ginger extract (highly } \\
\text { purified and standardized) }\end{array}$ & $\begin{array}{l}\text { Treatment of osteoarthritis } \\
\text { of the knee joints }\end{array}$ & $\begin{array}{l}\text { By reduction of inflammatory } \\
\text { mediators. }\end{array}$ & $\begin{array}{l}\text { (Bliddal et al., 2000; Altman } \\
\text { and Marcussen, 2001) }\end{array}$ \\
\hline [6]-gingerol and [6]-shogaol & anti-ulcerative effects & $\begin{array}{l}\text { By Suppressing the gastric contrac- } \\
\text { tion, increasing mucin secretion }\end{array}$ & (Minaiyan et al., 2006) \\
\hline $\begin{array}{l}\text { Sesquiterpenes (B- } \\
\text { Sesquiphellandrene) }\end{array}$ & Anti-viral effect & & (San Chang et al., 2013) \\
\hline Gingerol and shogaol & Antiplatelet activity & $\begin{array}{l}\text { lower platelet thromboxane } \mathrm{X} 2 \text { and } \\
\text { prostaglandin } \mathrm{E} 2 \text { production, }\end{array}$ & $\begin{array}{l}\text { (Nurtjahja-Tjendraputra et } \\
\text { al., 2003) }\end{array}$ \\
\hline Gingerol and shogaol & Hypotensive effects & $\begin{array}{l}\text { lowering blood pressure by inhibition } \\
\text { of voltage-dependent calcium } \\
\text { channels as well as by stimulating } \\
\text { muscarinic receptors }\end{array}$ & $\begin{array}{l}\text { (Ghayur et al., 2005; Nicoll } \\
\text { and Henein, 2009) }\end{array}$ \\
\hline Aqueous extract of ginger & $\begin{array}{l}\text { Hepato-protective effect } \\
\text { (against the CCl4, acetamino- } \\
\text { phen and lead) }\end{array}$ & $\begin{array}{l}\text { By decreasing ALT, AST and ALP } \\
\text { levels and enhancing the activities of } \\
\text { SOD, GST, CAT and GSH levels in the } \\
\text { liver }\end{array}$ & $\begin{array}{l}\text { (Bhandari et al., 2003; Bai et } \\
\text { al., 2011; Sabina et al., 2011; } \\
\text { Pratap and Indira, 2014) }\end{array}$ \\
\hline
\end{tabular}


Table 2: Phytochemical evaluation methods.

\begin{tabular}{|c|c|}
\hline Tests & Description \\
\hline Alkaloids test & $\begin{array}{l}5 \mathrm{ml} \text { of the ginger extracts were accurately measured and transferred into a flask and stirred with } 5 \mathrm{ml} \text { of } 1 \% \\
\text { aqueous hydrochloric acid on a steam bath. Then } 1 \mathrm{ml} \text { of that filtrate was treated with few drops of Dragen- } \\
\text { dorff's reagent. A color change to blue black was the evidence of presence of alkaloids. }\end{array}$ \\
\hline Saponins test & $\begin{array}{l}5 \mathrm{ml} \text { of the ginger extracts and } 5 \mathrm{ml} \text { distilled water in a test tube. Appearance of Frothing on shaken with water } \\
\text { showed the presence of saponins. }\end{array}$ \\
\hline Tannins test & $\begin{array}{l}5 \mathrm{ml} \text { of the ginger extracts along with } 100 \mathrm{ml} \text { distilled water and filtered, then ferric chloride reagents was } \\
\text { added, blue-black or blue green precipitate appeared which showed the presence of Tannins. }\end{array}$ \\
\hline Phlobotannins test & $\begin{array}{l}\text { When an aqueous extract of the test sample (ginger) was boiled with } 1 \% \text { hydrochloric acid, disposition of red } \\
\text { precipitate had confirmed the presence of phlobotannins. }\end{array}$ \\
\hline Flavonoids test & $\begin{array}{l}\text { When } 5 \mathrm{ml} \text { of diluted ammonia solution was added to aqueous filtrate of the test sample (ginger extract) } \\
\text { followed by the addition of concentrated } \mathrm{H}_{2} \mathrm{SO}_{4} \text {, a yellow coloration was observed which determined the } \\
\text { presence of flavonoids. }\end{array}$ \\
\hline $\begin{array}{l}\text { Cardiac glycosides } \\
\text { (keller-killiani test) }\end{array}$ & $\begin{array}{l}\text { When } 5 \mathrm{ml} \text { of the ginger extracts dissolved in } 2 \mathrm{ml} \text { glacial acetic acid containing a drop of ferric chloride } \\
\text { solution was underplayed with } 1 \mathrm{ml} \text { concentrated } \mathrm{H}_{2} \mathrm{SO}_{4} \text {. A brown ring appeared at interface indicated } \\
\text { adeoxy-sugar characteristic of cardenolides. A violet ring may appear below the brown ring, while in the } \\
\text { acetic acid layer, a green ring may form just gradually spread throughout this layer. }\end{array}$ \\
\hline Steroids test & $\begin{array}{l}\text { When } 2 \mathrm{ml} \text { of acetic anhydride was added to } 0.5 \mathrm{~g} \text { of ginger extract and } 2 \mathrm{ml} \text { of sulphuric acid was added by } \\
\text { the sides of the test tube a color change was observed to violet or blue-green which showed the presence of } \\
\text { steroids }\end{array}$ \\
\hline Terpenoids test & $\begin{array}{l}\text { When } 2 \mathrm{ml} \text { of chloroform was added to } 1 \mathrm{ml} \text { of the extract, and Conc. } \mathrm{H}_{2} \mathrm{SO}_{4}(3 \mathrm{ml}) \text { was added to form a layer, } \\
\text { a reddish brown coloration at the interface indicated the presence of terpenoid. }\end{array}$ \\
\hline
\end{tabular}

with slight modification, were used for the screening of alkaloids, steroids, phlobotannins, flavonoids, glycosides, saponins, tannin and terpenoids (table 2).

\section{Antimicrobial assay}

The antimicrobial activity of ginger extract against various human pathogens was determined by agar diffusion method.

Four bacterial cultures were used, named Staphylococcus aureus, Escherichia coli, Bacillus subtilis and Streptococcus faecalis. Soybean-Casein Digest Agar (SCDA) was used as the culture media. Sterile saline tubes $(5 \mathrm{ml})$, $70 \%$ IPA, sterile test tubes, sterile petri-plates, $250 \mathrm{ml}$ conical flasks, Borer, Micropipette, sterile tips, sterile inoculating loop, autoclave, shaker, oven $\left(32-35^{\circ} \mathrm{C}\right)$, laminar air flow hood, incubator, weighing balance and Vernier caliper were used for the assav.

From cultures of E. Coli, Bacillus subtilis, Staphylococcus aureus and Streptococcus faecalis, slants were made and incubated at $32^{\circ} \mathrm{C}$ for $24-48 \mathrm{hrs}$. Loops from each slant culture were transferred separately in $5 \mathrm{ml}$ sterile saline solution tube to prepare suspension of each culture. These suspensions were transferred separately to $150 \mathrm{ml}$ sterile SCDA when cooled to a temperature of $40-45^{\circ} \mathrm{C}$. Each conical flask having SCDA and culture suspension was shaken to allow uniform distribution of microbial cells in medium. After shaking each SCDA medium with culture suspension was poured into four plates, labeled and allowed to solidify. After solidification of the medium in plates, the wells were cut in each plate using sterile borer. $0.1 \mathrm{ml}$ of $10 \%(\mathrm{w} / \mathrm{v})$ ginger extract to be tested was poured into different wells and the plates were incubated at $32^{\circ} \mathrm{C}$ for $24 \mathrm{hrs}$. After incubation the plates were observed for the presence of zone of inhibition. If present, the diameter of zone of inhibition was measured with the help of vernier caliper.

Two fungi cultures were also used, namely Candida albicans and Aspergillus niger. Sabouraud dextrose agar
(SDA) was used as culture media. Sterile saline tubes $(5 \mathrm{ml}), 70 \%$ IPA, sterile test tubes, sterile Petri plates, $250 \mathrm{ml}$ conical flasks, Borer, Micropipette, sterile tips, sterile inoculating loop, autoclave, shaker, oven $\left(32-35^{\circ} \mathrm{C}\right)$, laminar air flow hood, incubator, weighing balance and Vernier caliper were used for the assay.

From cultures of Candida albicans and Aspergillus Niger, slants were made and incubated at $22^{\circ} \mathrm{C}$ for $24-48 \mathrm{hrs}$. A loop from each slant culture was transferred separately in $5 \mathrm{ml}$ sterile saline solution tube to prepare suspension of each culture. This $5 \mathrm{ml}$ suspension of each culture were transferred separately to $150 \mathrm{ml}$ sterile SDA when cooled to a temperature of $40-45^{\circ} \mathrm{C}$. Each conical flask having SDA and culture suspension was shaken to allow uniform distribution of microbial cells in medium. After shaking each SDA medium with culture suspension was poured in three plates, labeled and allowed to solidify. After solidification of the medium in plates, the wells were cut in each plate using sterile borer. $0.1 \mathrm{ml}$ of $10 \%(\mathrm{w} / \mathrm{v})$ extract of ginger plant to be tested was poured into different wells. The plates were incubated at $22^{\circ} \mathrm{C}$ for 24 hrs. After incubation the plates were observed for the presence of zone of inhibition. If present, the diameter of zone of inhibition was measured with the help of vernier caliper.

\section{RESULTS AND DISCUSSION}

\section{Phytochemical screening}

Phytochemical screening of chloroform plant extract showed presence of alkaloid, phlobotannins, flavanoids, glycosides, saponins, tannin and terpenoids and absence of steroids (table 3 ).

\section{Antimicrobial assays}

The findings of the present study revealed that Zingiber officinale contain potent antimicrobial property against tested microbes. The antimicrobial activity of the ginger extracts (chloroform extract) was initially evaluated by 
Table 3: Qualitative phytochemical analysis of crude extract of Zingiber officinale (Ginger roots).

\begin{tabular}{lcc}
\hline $\begin{array}{c}\text { Bioactive } \\
\text { principle }\end{array}$ & $\begin{array}{c}\text { Chloroform extract } \\
\text { of ginger }\end{array}$ & $\begin{array}{c}\text { Methanol extract } \\
\text { of ginger }\end{array}$ \\
\hline Alkaloids & +++ & +++ \\
Tannins & ++ & ++ \\
Glycosides & ++ & ++ \\
Saponins & +++ & +++ \\
Steroids & - & - \\
Flavonoids & ++ & ++ \\
Terpenoids & + & + \\
Pholobotannins & + & + \\
\hline Key $=+++$ abundantly present, + fairly present, ++ moderately present, -absent
\end{tabular}

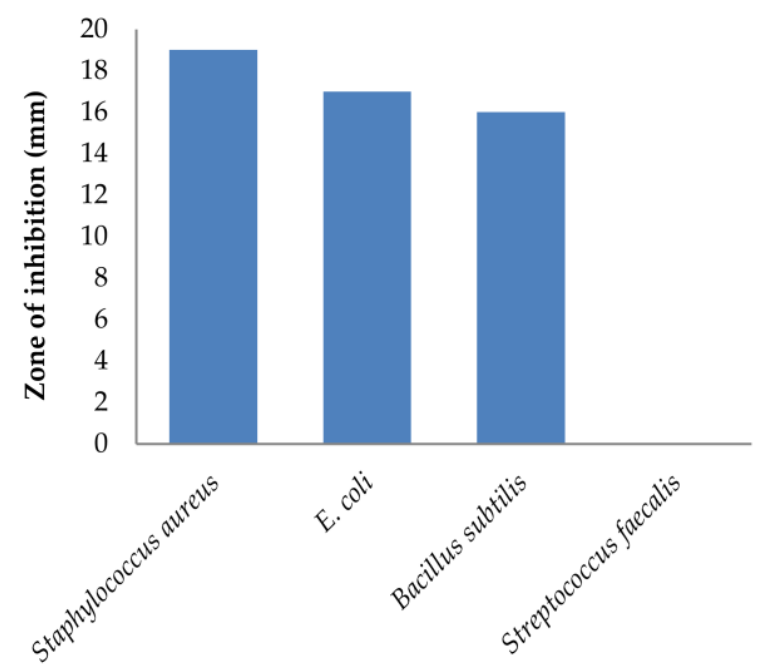

Figure 2: Zone of inhibition of bacteria - ginger extract has shown maximum antimicrobial activity towards $S$. aureus.
Table 4: Degree of sensitivity of bacteria plus fungi against ginger extract by measuring zone of inhibition.

\begin{tabular}{cccc}
\hline \multicolumn{2}{c}{ Microorganisms } & NCIM NO & $\begin{array}{c}\text { Zone of } \\
\text { inhibition } \mathbf{( m m} \text { ) }\end{array}$ \\
\hline Bacteria & Staphylococcus aureus & 2079 & 19 \\
& E. coli & 2065 & 17 \\
& Bacillus subtilis & 2063 & 16 \\
\multirow{2}{*}{ Fungi } & Streptococcus faecalis & 5024 & - \\
& Candida albicans & 3471 & - \\
& Aspergillus Niger & 1196 & 20 \\
\hline
\end{tabular}

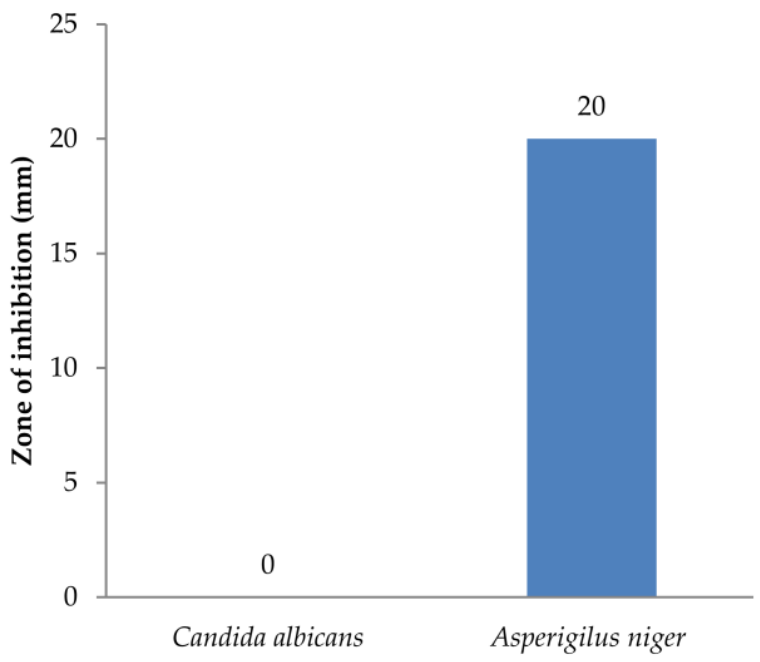

Figure 3: Zone of inhibition of fungi - ginger extract has shown maximum antifungal activity towards Aspergilus niger.

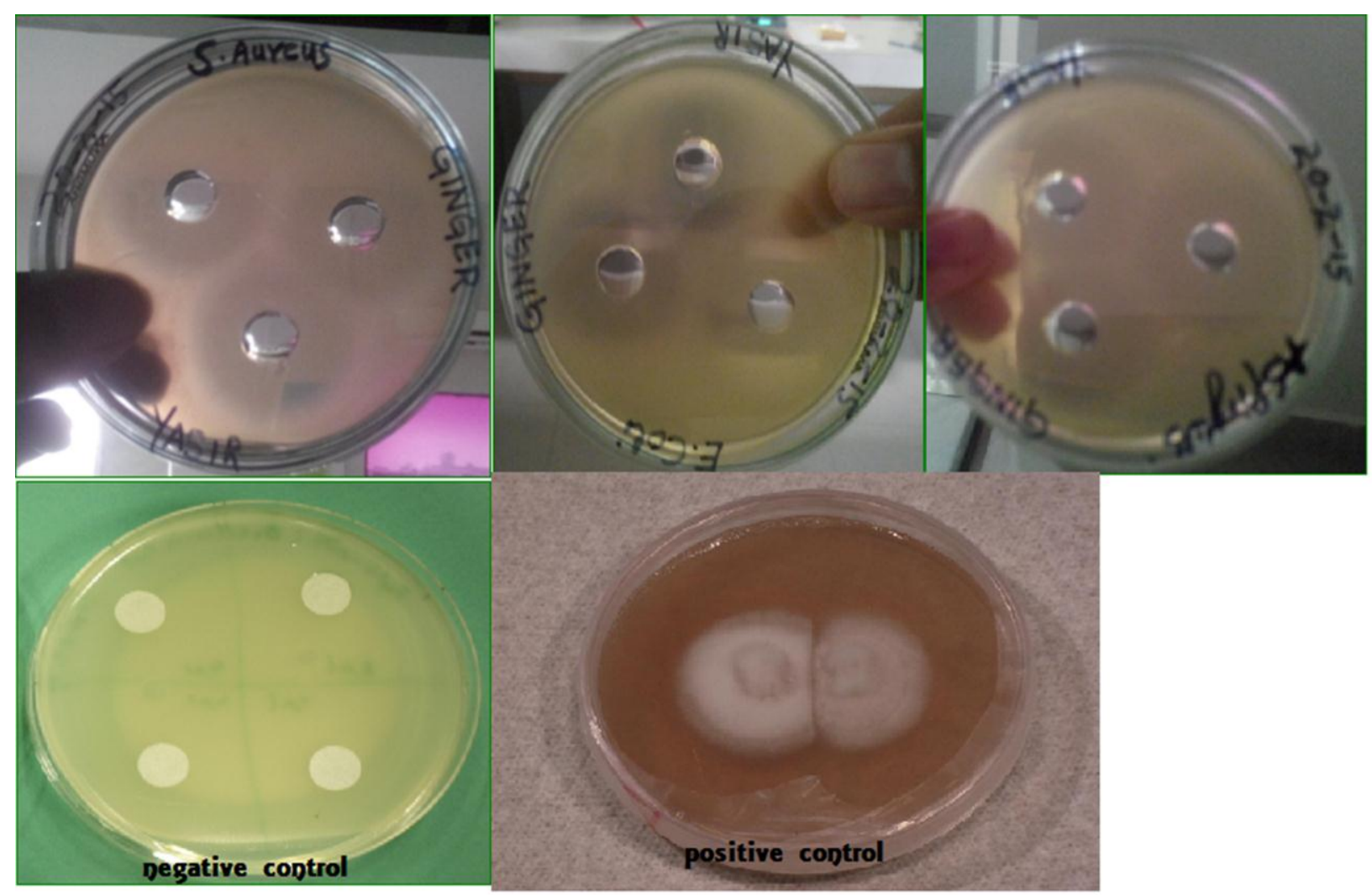

Figure 4: Zone of inhibition on Nutrient agar and Sabouraud Dextrose Agar. 
agar diffusion method using four strains of pathogenic bacteria Escherichia Coli, Bacillus subtilis, Staphylococcus aureus, Streptococcus faecalis and two stains of fungi Candida albicans and Aspergillus Niger. These extracts exhibited antimicrobial activity (table 4, figure 2-4).

\section{CONCLUSION}

The results of our experiments showed that different bacterial species exhibited different sensitivities towards the extract of ginger. Today, most pathogenic organisms are becoming resistant to antibiotics. To overcome this alarming problem, the discovery of novel active compounds against new targets is a matter of urgency. Most of the spices extracted either in water or in organic solvents have biologically active compounds, which can be used in the synthesis of potent drugs. Thus spices, which are normal ingredients of our routine food preparations, can provide protection to a certain extent against our natural enemies like bacterial pathogens

\section{REFERENCES}

Altman, R.D., Marcussen, K.C., (2001). Effects of a ginger extract on knee pain in patients with osteoarthritis. Arthritis Rheum, 44(11), 2531-2538. [DOI]

Bai, X., Zhang, W., Chen, W., Zong, W., Guo, Z., Liu, X., (2011). Anti-hepatotoxic and anti-oxidant effects of extracts from Piper nigrum l. Root. African Journal of Biotechnology, 10(2), 267-272.

Baliga, M.S., Haniadka, R., Pereira, M.M., Thilakchand, K.R., Rao, S., Arora, R. (2012). Radioprotective effects of Zingiber officinale roscoe (ginger): Past, present and future. Food \& function, 3(7), 714-723. [DOI]

Bhandari, U., Shamsher, A.A., Pillai, K., Khan, M., (2003). Antihepatotoxic activity of ginger ethanol extract in rats. Pharmaceutical biology, 41(1), 68-71. [DOI]

Bhosale, K.S., Shinde, B.P., (2011). Influence of arbuscular mycorrhizal fungi on proline and chlorophyll content in Zingiber officinale rosc grown under water stress. Indian Journal of Fundamental and Applied Life Sciences, 1 (3): 172-176.

Bliddal, H., Rosetzsky, A., Schlichting, P., Weidner, M.S., Andersen, L.A., Ibfelt, H.H., Christensen, K., Jensen, O.N., Barslev, J., (2000). A randomized, placebocontrolled, cross-over study of ginger extracts and ibuprofen in osteoarthritis. Osteoarthritis Cartilage, 8(1), 9-12. [DOI]

Bolanle, A.O., (2011). Effect of ginger powder (Zingiber officinale) on plasma lipid profile and liver enzyme activities of hypercholesterolemic rats. JLS, 5, 712-716.

Boyd, I.W., (1999). Angiotensin receptor antagonists. Aust Prescr, 22(3), 53-54.

Bryer, E., (2005). A literature review of the effectiveness of ginger in alleviating mild-to-moderate nausea and vomiting of pregnancy. Journal of Midwifery \& Women's Health, 50(1), e1-e3. [DOI]

Chang, C., Griffith, G., Maino, G., (2011). The feasibility of fresh ginger exports from Papua New Guinea to New Zealand. Australasian Agribusiness Review, 19, 7597.

Cramb, R., Garcia, J., Gerrits, R., Saguiguit, G., (2000). Conservation farming projects in the philippine uplands: Rhetoric and reality. World Development, 28(5), 911-927. [DOI]

El-Ghorab, A.H., Nauman, M., Anjum, F.M., Hussain, S., Nadeem, M., (2010). A comparative study on chemical composition and antioxidant activity of ginger (Zingiber officinale) and cumin (Cuminum cyminum). Journal of agricultural and food chemistry, 58(14), 8231-8237. [DOI]

Fessenden, J.M., Wittenborn, W., Clarke, L., (2001). Gingko biloba: A case report of herbal medicine and bleeding postoperatively from a laparoscopic cholecystectomy. Am Surg, 67(1), 33-35.

Ghayur, M.N., Gilani, A.H., Afridi, M.B., Houghton, P.J., (2005). Cardiovascular effects of ginger aqueous extract and its phenolic constituents are mediated through multiple pathways. Vascular pharmacology, 43(4), 234-241. [DOI]

Govindarajan, V., Connell, D., (1983). Ginger-chemistry, technology, and quality evaluation: Part 1. Critical Reviews in Food Science \& Nutrition, 17(1), 1-96. [DOI]

Iqbal, Z., Lateef, M., Akhtar, M.S., Ghayur, M.N., Gilani, A.H., (2006). In vivo anthelmintic activity of ginger against gastrointestinal nematodes of sheep. Journal of ethnopharmacology, 106(2), 285-287. [DOI]

Kadnur, S.V., Goyal, R.K., (2005). Beneficial effects of Zingiber officinale roscoe on fructose induced hyperlipidemia and hyperinsulinemia in rats. Indian journal of experimental biology, 43(12), 1161.

Lantz, R., Chen, G., Sarihan, M., Solyom, A., Jolad, S., Timmermann, B., (2007). The effect of extracts from ginger rhizome on inflammatory mediator production. Phytomedicine, 14(2), 123-128. [DOI]
Ling, H., Yang, H., Tan, S.H., Chui, W.K., Chew, E.H., (2010). 6-shogaol, an active constituent of ginger, inhibits breast cancer cell invasion by reducing matrix metalloproteinase-9 expression via blockade of nuclear factor-kb activation. British Journal of Pharmacology, 161(8), 1763-1777. [DOI]

Macleod, A.J., Pieris, N.M., (1984). Volatile aroma constituents of Sri Lankan ginger Phytochemistry, 23(2), 353-359. [DOI]

Maldonado, A., (1920). Contribución al estudio de la materia médica peruana. In: Proceedings of the Anales de la Facultad de Medicina, pp. 250-272. [DOI]

Maxwell, I., (2008). Let's make ginger beer. Dave's Garden.

Minaiyan, M., Ghannadi, A., Karimzadeh, A., (2006). Anti-ulcerogenic effect of ginger (rhizome of Zingiber officinale roscoe) on cystemine induced duodenal ulcer in rats. DARU Journal of Pharmaceutical Sciences, 14(2), 97-101.

Naveena, B., Mendiratta, S., Anjaneyulu, A., (2004). Tenderization of buffalo meat using plant proteases from Cucumis trigonus roxb (kachri) and Zingiber officinale roscoe (ginger rhizome). Meat Science, 68(3), 363-369. [DOI]

Newman, S., Bennett, K., Wu, Y., (1997). Performance of maize, beans and ginger as intercrops in paulownia plantations in china. Agroforestry Systems, 39(1), 2330. [DOI]

Nicoll, R., Henein, M.Y., (2009). Ginger (Zingiber officinale roscoe): A hot remedy for cardiovascular disease? International journal of cardiology, 131(3), 408-409. [DOI]

Nurtjahja-Tjendraputra, E., Ammit, A.J., Roufogalis, B.D., Tran, V.H., Duke, C.C. (2003). Effective anti-platelet and cox-1 enzyme inhibitors from pungent constituents of ginger. Thromb Res, 111(4-5), 259-265. [DOI]

Panhwar, F., (2005). Ginger (Zingiber officinale rose) cultivation in sindh pakistan. Digitalverlag GMBH Publishing: Germany.

Penna, S.C., Medeiros, M.V., Aimbire, F.S., Faria-Neto, H.C., Sertie, J.A., LopesMartins, R.A., (2003). Anti-inflammatory effect of the hydralcoholic extract of Zingiber officinale rhizomes on rat paw and skin edema. Phytomedicine, 10(5), 381-385. [DOI]

Powell, J.M., (1986). Manure for cropping: A case study from central nigeria. Experimental Agriculture, 22(01), 15-24. [DOI]

Pratap, M., Indira, P., (2014). Protective effects of ginger (Zingiber officinale) extract against lead induced oxidative stress on liver antioxidant enzymes in male albino rats. International Journal of Pharma \& Bio Sciences, 5(2).

Rahman, H., Karuppaiyan, R., Kishore, K., Denzongpa, R., (2009). Traditional practices of ginger cultivation in northeast india. Indian Journal of Traditional Knowledge, 8(1), 23-28.

Ravindran, P., Babu, K.N., (2004). Ginger: The genus zingiber CRC Press.

Sabina, E.P., Pragasam, S.J., Kumar, S., Rasool, M., (2011). 6-gingerol, an active ingredient of ginger, protects acetaminophen-induced hepatotoxicity in mice. Journal of Chinese Integrative Medicine: 9(11): 1264-1269. [DOI]

San Chang, J., Wang, K.C., Yeh, C.F., Shieh, D.E., Chiang, L.C., (2013). Fresh ginger (Zingiber officinale) has anti-viral activity against human respiratory syncytial virus in human respiratory tract cell lines. Journal of Ethnopharmacology, 145(1), 146-151. [DOI]

Shanmugam, K.R., Mallikarjuna, K., Kesireddy, N., Reddy, K.S., (2011). Neuroprotective effect of ginger on anti-oxidant enzymes in streptozotocininduced diabetic rats. Food and chemical toxicology, 49(4), 893-897. [DOI]

Shelly, T.E., Mcinnis, D.O., Pahio, E., Edu, J., (2004). Aromatherapy in the Mediterranean fruit fly (diptera: Tephritidae): Sterile males exposed to ginger root oil in prerelease storage boxes display increased mating competitiveness in field-cage trials. Journal of Economic Entomology, 97(3), 846-853. [DOI]

Shukla, Y., Singh, M., (2007). Cancer preventive properties of ginger: A brief review. Food and chemical toxicology, 45(5), 683-690. [DOI]

Sloand, E.D., Vessey, J.A., (2001). Self-medication with common household medicines by young adolescents. Issues Compr Pediatr Nurs, 24(1), 57-67. [DOI]

Srivastava, K.C., Mustafa, T., (1989). Ginger (Zingiber officinale) and rheumatic disorders. Med Hypotheses, 29(1), 25-28. [DOI]

Suekawa, M., Ishige, A., Yuasa, K., Sudo, K., Aburada, M., Hosoya, E., (1984). Pharmacological studies on ginger. I. Pharmacological actions of pungent constituents,(6)-gingerol and (6)-shogaol. Journal of Pharmacobio-Dynamics, 7(11), 836-848. [DOI]

Surh, Y.-J., Park, K.-K., Chun, K.-S., Lee, L., Lee, E., Lee, S.S., (1998). Anti-tumorpromoting activities of selected pungent phenolic substances present in ginger. Journal of environmental pathology, toxicology and oncology: official organ of the International Society for Environmental Toxicology and Cancer, 18(2), 131139.

Vats, V., Grover, J.K., Rathi, S.S., (2002). Evaluation of anti-hyperglycemic and hypoglycemic effect of Trigonella foenum-graecum linn, Ocimum sanctum linn and Pterocarpus marsupium linn in normal and alloxanized diabetic rats. J Ethnopharmacol, 79(1), 95-100. [DOI]

Williams, P., Winks, C., Rijkse, W., (2003). Forest processes in the presence of wild ginger (Hedychium gardnerianum). New Zealand Journal of Ecology, 27(1), 45-54. 